\title{
Literary Translation and Cultural Challenges: JhumpaLahiri's The Namesake
}

\author{
Sura M. Khrais \\ Department of English Language and Literature, Al-Balqa Applied University, Jordan
}

Received: 17-11-2016

doi:10.7575/aiac.ijclts.v.5n.1p.80
Accepted: 29-01-2017

Published: 31-01-2017

\begin{abstract}
This paper discusses how the nature of literary translation differs from other forms of translation by looking at practical difficulties and challenges notable in the Arabic translation of Lahiri's novel The Namesake (2003). The difficulties discussed are cultural differences which have created "untranslatable" cultural-bound words and phrases, as well as specialized vocabulary. The paper explores the conflict between the translator's duty to accuracy and his/her duty to literary translation as an art form. One problem faced by the prose-translator is finding terms in his or her own language that are faithful as much as possible to the meaning of certain words in S.L. For example, there are words which describe specific rituals or those related to typical architecture, fabrics, and cookery; these and many others represent the specific culture of the original text and the translator needs to be careful when translating them. The researcher finally suggests that there is a need to expand the perimeters of translation studies specially those dealing with literary prose because the translators and researchers lay more emphasis on the translation of poetry.
\end{abstract}

Keywords: Literary translation, cultural differences, untranslatability, source and target language, cultural anomaly

\section{Introduction}

When the written work of one language is recreated in another, the translator faces many challenges, which require bold and creative steps on his/her part to introduce an illegible text in the target language (T.L.). The difference in culture between the source language (S.L.) and the target language (T.L.) may result in a confusing reading and an ambiguous translation. One problem faced by the prose-translator is finding terms in his or her own language that are faithful as much as possible to the meaning of certain words in S.L. For example, there are words which describe specific rituals or those related to typical architecture, fabrics, and cookery; these and many others represent the specific culture of the original text and the translator needs to be careful when translating them. One of the most common challenges to the literary translator is cultural anomaly, that is, when an equivalent word does not exist in the T.L. and that word may have a host of cultural connotations which are not part of the Target culture as well. Lacking exact equivalents in Arabic motivates the translator to hoist the white flag, use transliterations and add footnotes. Ironically, such technique which is sometimes the translator's lifebuoy, serves to remind him or her of what is missing in the translation. Though the translator's notes may result in many stops during the process of reading the Target Text (T.T.), this paper will show that without them the text will be less fluently-readable. Notes prevent the T.T. from being more foreign and distant to the reader who belongs to a different culture. The translator does his or her best to introduce a more authentic picture of the source culture. E. A. Nida (1982) believes that translation tries to connect a wide cultural gap and it is not possible for the prose translators to remove all the marks of foreign setting. According to her, it is normal that the source and receptor languages may possibly represent very different cultures that may include many basic themes and descriptions, which cannot 'naturalize' by the process of translating (105).

Nevertheless, there are limits to the translator's interference in the Source Language because after all translation is "rendering the meaning of a text into another language in the way that the author intended the text" (Newmark 1988, 5) and not the way the translator likes the text to be. The good literary translator tries his best to create a balance between comprehensibility and truth to the original text, its local setting and specific culture. On the other hand, it is the translator's goal to render the meaning of the original text in such a way that readers of T.T. will enjoy the text as much as readers of S.T. In addition, the literary translator does not simply translate the content of the S.T. but he or she tries to find out its message and what culture it tries to communicate. HomiBhabha (1994) suggests that "translation is the performative nature of cultural communication" (228). Yet, there is normally no full equivalence through translation of the S.T but, as Roman Jakobson (1959) suggests we may end with a satisfactory analyses of code units or messages (88). The French theorist, Georges Mounin agrees with Jakobson. Mounin perceives translation as " a series of operations of which the starting point and the end product are 'significations' and function within a given culture" (Cited in Susan Bassnett 1980, 15).

A good literary prose translation shows that language has not only a communicative purpose but also societal and cultural flavors that distinguish the Source Text. the translator cannot escape the complexities of differences between cultures. Walter Benjamin(1968) describes "cultural difference" which is a problematic issue in translation as "the irresolution, or liminality, of 'translation', the element of resistance in the process of transformation, 'that element in a translation which does not lend itself to translation"' (75). In this context, a straightforward word-for-word substitution 
may not always be possible. Some believe that the central problem of translation practice is that of finding TL equivalents (Catford, 1965). The translator finds himself or herself caught between the desire to translate literally or "metaphrase" (Hque 2012, 97) which is difficult in this context, to paraphrase in order to avoid wrong equivalents between the Source and Target Texts, or desperately to transliterate many words in the SL. Bhabha's words reflect the translator's impossible mission when the earlier says: "each cultural naming represents the impossibility of crosscultural identity or symbolic synapses; each time there repeats the incompletion of translation" (130).

\section{The Problem Statement}

This paper deals with the practical difficulties and challenges faced by the translator. These difficulties have created "untranslatable" cultural-bound words and phrases. The Source English Text (ST) is JumphaLahiri's novel The Namesake (2003) and the Target Text (TT) is the Arabic translation of the novel by SuraKhrais (2015). It is worth mentioning that Lahiri is an American novelist of a Bengali origin and Buddhist faith.

\section{Discussion: Untranslatable cultural-bound words}

1. In describing a class that Lydia, Maxine's mother, studied at college, the narrator says,

"... a college class she'd once taken on Buddhist stupas." (p. 134)

The translation into Arabic is:"

$$
\text { تتحدث عن مساقٍ درسته في الجامعة عن ،الستوباُ1 أو أماكن التأمل الهندوسية" (ص. 221). }
$$

Since 'Stupas' are not part of the TT culture, it has no equivalent word in Arabic. The translator had to transliterate the term (/stūpa/) and paraphrase it at the same time as "places of meditation in Hindu". A footnote to introduce further information about such worship places was important. The footnote suggests that a stupa is a mound-like or hemispherical structure containing "relics", typically the remains of Buddhist monks or nuns, used as a place of meditation.

2. Another reference to 'pujos' rituals appears frequently to describe the religious activities of the Gangoli's family which Gogol loses interest in as a young man who lives away from his family now:

"He didn't want to go home on the weekend, to go with them to pujos and Bengali parties..." (126).

The translation is:

" لم ير غب غو غول بالعودة إلى منزل و الديه في عطلة نهاية الأسبوع ومر افقتهما للمشاركة في طقوس البوجاii وحضور الحفلات البنغالية" (208).

Pujo (/pujja//) comes from Sanskrit, and means reverence, honor, homage, adoration, and worship.It is a prayer ritual performed by Hindus to host, honor and worship one or more deities or to spiritually celebrate an event. There is no word-for-word reference in Arabic which reflects its features as a Hindu ritual held by Buddhists, Jains and Sikhs. So transliteration of the term and a footnote to explain its meaning is the best thing a translator can do.

3. A Hebrew word which refers to a Jewish ritual also appears:

"He has worn a tie once in his life, to attend a friend's bar mitzvah" (75)

The translation was:

$$
\text { " ارتدى غو غل ربطة عنق مرةً واحدةً في حياته عندما دعاه صديقه اليهودي إلى حفل بار متسفاiilii الخاص به" (127) }
$$

'Bar mitzvah' is a Jewish ritual to celebrate a boy turning thirteen which means he becomes accountable for his actions and responsible for all religious duties dictated by Jewish religious laws known in Hebron as Halakhah((/ha:'lo:xə/). Similarly, the word is transliterated because there is no word-for-word translation of the term in the TL and a footnote explains its meaning.

4. Another ritual which is associated with the idea of growing up is "annaprasan" or "rice ceremony" (30) which replaces baptism. Literally the term means 'food feeding' which suggests the baby's first meal. The narrator explains the ritual as "rice ceremony". In other words, Gogol's first meal as a baby is rice:

"The occasion: Gogol's annaprasan, his rice ceremony. There is no baptism for Bengali babies, no ritualistic naming in the eyes of God" (38).

The translation is:

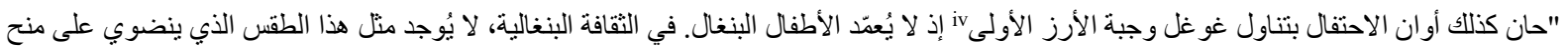

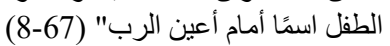

5. Other terms have to do with architecture and they have no Arabic equivalence; however, a transliterated term is already found in the TL well known to architects. For instance, Gogol notices the architecture which distinguishes Maxine's parents' house:

"He notices the pedimented window lintels, the Doric pilasters..." (130)

The translation is:

$$
\text { "يلاحظ غو غول الحافة المقوصرة (المحدبة) للنو افذ والأعمدة الدوريسية"..." (214) }
$$

The footnote shows that Doric pilasters are one of three distinguishing features of the Greek architecture. Similarly, some buildings have a "Tudor facades" (174) and the translation is:

$$
\text { "كان لتلك المباني واجهةٌ من الطر از التيودوري" }
$$

Such architecture is a revival of the Tudor style which distinguished buildings during the Tudor period. Both words "Doric" and "Tudor" are transliterated. On the other hand, many references to the architecture of different buildings are simply paraphrased in TT depending on their original meanings in the source culture which is Greek. Gogol admires the windows of Maxine's parents' house:

"Lovely freieze- band window" (132).

The translation refers to them simply as "Greek windows":

"هذه النو افذ الإغريقيةةii جميلةٌ" (217).

The footnote shows that these special Greek windows have an equivalent term in Arabic which is:

$$
\text { "طُنْف" و هو ما أشرف خارجا عن البناء (قاموس المعاني) }
$$


The word in classical Arabic means a window with salient angles. However, the translator chooses not to use this word because an average reader might not be familiar with. On the other hand, it is also known among architects by its transliterated term:

6. Many architectural terms which are part of the source culture have become familiar in the target culture such as "the Juliet balcony" (288) of the bedroom which is translated as:

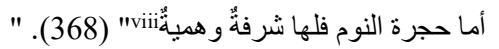

The footnote shows that such balcony is also known in the Target culture as "Romeo and Juliet balcony":

$$
\text { شرفة روميو وجوليوت }
$$

and that it is not an actual balcony. It does not protrude out of the building. Modern Juliet balconies often involve a metal barrier placed in front of a high window which can be opened. Similarly, a "French door" (130) is not French at all. It is made of glass:

On the other hand, some architectural terms are confusing as the word "skylight" in the following sentence:

"There is a living room with a skylight..." (228)

The translation is:

"ولحجرة المعيشة منور (كوة) وسط السقف..." (368)

So, the "skylight" is an overhead window, as in a roof, admitting daylight. The word has two equivalents in Arabic as the translation shows. Average readers might be more familiar with the first word (/manwar/) than the second one (/k uwwa/).

7. The Source Text introduces many other culturally specific terms such as the references to certain gifts, fabrics or food.

"It was only after the salesman had wrapped it that she'd remembered the rule about giving paper on the first anniversary" (247)

The translation is:

$$
\text { "عندما ابتاعت موشومي القميص لم تتذكر القاعدة الخاصة بعيد الزو اج الأول و التي تتص على تقديم هديةٍ ورقيةٍ إلا بعد أن قام البائع بتغليف القميص." }
$$

Therefore, the word "paper" which is apparently associated with some tradition stands for a paper gift such as a love letter, a framed photograph, a poster or even a book.

8. In addition, a traditional design of a leaf used as face painting in Bengali weddings is known as "paisleys". In her wedding, Moushumi's cheeks are adorned with "paisleys".

"Two enormous paisleys have been painted in red and white on her cheeks". (222)

The translation is:

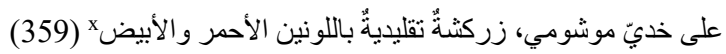

"Paisleys" are Indian face painting of a Persian origin and a paisley has the shape of a leaf which has become a distinguishing feature of Kashmiri shawls. Americans call it 'Persian pickles' while Welsh people call it 'Welsh pears'. The translator chooses to refer to it as a traditional adornment rather than pickles or pears!

9. The reference to special playing cards which are not part of the target culture is transliterated:

"Astrid is showing a few people paint chips, which she's lined up in front of her like tarot cards..." (237).

"أما أستريد فتعرض عيناتٍ ورقيةً صغيرةً لطلاء جدرانٍ...على بعض الأشخاص، فتصنفّها أمامها مثل أوراق التارو xi" (383)

"Tarots" are (/'tæroð/) playing cards bearing allegorical representations, used for fortunetelling. The transliterated term (/tārau/) is vague for the reader of the TT unless it is paraphrased in a footnote.

10. Furthermore, some food which is part of the source culture is translated literally in the TT; however, a footnote is essential to avoid confusion. In the following sentence, a special kind of goat cheese is described:

"Back in the kitchen she sets out some olives and some goat cheese coated with ash" (208)

The translation is:

"في المطبخ كانت موشومي تضع قلبياً من الزيتون وجبن الماعز المغطى بالرماد "xii" (338)

It is cheese which is literally coated with ashes. In the history of making cheese, tasteless ashes which have no smell and which result from burning salt and dried vegetables are added to cheese so that it looks delicious. Without a footnote to clarify this feature of a goat cheese, the reader would be misled.

11. On the other hand, some dishes are not part of the target culture such as "dal" (/da:1/)which is a thick stew prepared from dried grains such as lentil, peas, and beans. It is an important part of the Bangladeshi cuisine. So, the translator depends on components of the dish (dry grains) to translate the word:

"...he likes to finish his dinner with a small final helping of rice anddal (10)."

The translation is:

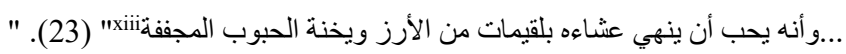

12. Another Bengali dish is "korma of lamb" (277). The word 'korma' is from Turkish (kavurma) and it means 'cooked meat' . It is transliterated as:

$$
\text { كورمة أو كورما بالتركية }
$$

However, the word may be confused for another Turkish dish known as Shawarma or shawurma from the Turkish word çevirme [t $\mathrm{t}$ evir' me] which is also derived from the Arabic prefix 'shawa' which means roasting meat and translated as شاورما (shāwarmāa) 
Korma, in the Bangladeshi cuisine, consists of meat or fish and vegetables braised in a spiced sauce made with yogurt, cream, nut or seed paste which is not a feature of Shawarma. So, "korma" acquires special features in the Bangladeshi cuisine different from those in Shawarma. For this reason, the translator prefers a transliteration of the word and a footnote to explain its components:

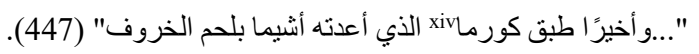

13. Similarly, "croquettes" (286) are a typical dish in the Bangladeshi cuisine. "Croquette" is a small cake of minced food, such as meat, poultry, vegetables, or fish, that is usually coated with bread crumbs and fried in deep fat. Croquettes are usually shaped in rolls or balls. The ST does not suggest which components Ashima has chosen for her croquettes. The translator emphasizes the ball shape while transliterating the word "croquettes". Therefore, the translator refers to them as:

"The croquettes are fried in crackling oil..." (286).

$$
\text { "كر ات الكروكيت" التي تقليها أثنيما في الزيت الساخن (459) }
$$

14. In addition, Maxine and her mother prepare "paella" dish (/pa'er ə/, Spanish: /pa'eאa/) which is a saffron-flavored Spanish dish made with varying combinations of rice, vegetables, meat, chicken, and seafood. Maxine and her mother choose to prepare it with seafood (156). Since the dish is not part of the target culture, the translator decides to transliterate it as it is pronounced in Spanish (the /1/ sound is silent):

قررتا أن تعدا طبق البائيا الإسباني xas" (258) " 15. Another example is "pesto" (154) which is an Italian sauce that traditionally consists of crushed garlic, basil, and European pine nuts blended with olive oil. The word "pesto" (Italian pronunciation: ['pesto]) has no equivalence in the TL. Again a transliteration of the term and a footnote to describe its components is the translator's best solution:

"معكرونةٌ بصلصة البيستو الإيطالية:xin" (254)

16. Finally, Ashima prepares "samosas" (/sə'mousə/) (149)- fried pastry with spiced filling- among other dishes to welcome Gogol's girlfriend. There are variable transliterated terms for the word in google website:

$$
\text { السنبوسة أو السنبوسك أو السمبوسة أو السمبوسك }
$$

Depending on the way the word is pronounced in the target language (/so'mousə/), the translator chooses a different transliterated term:

$$
\text { "الساموسة" (245) }
$$

17. Some drinks are known by their brand names which are not familiar in the TL. The untranslatability of the terms is obvious. The reference to "punch", Horlick's, "LapsangSouchong" and "Lopchu tea" create a new challenge to the translator.

"For the rest of the day, they sit at a communal round table, drinking punch..." (60)

The translation is:

"He and Sonia are given cups of Horlicks" (82).

$$
\text { "أما بقية اليوم فيجلس الأطفال في مجمو عاتٍ حول طاولةٍ مستديرةٍ ويشربون عصير البنش xvii... (82)." }
$$

The translation is:

"تُقدم لهما أكو ابٌّ من مشروب هورليك الساخن

While punch is a fruit juice, and Horlicks is a brand of milk flavoring malt powder, the brand name is more frequent in the ST.

18. Similarly, "LapsangSouchong" (/, læpsæy 'su:tfpy/) is a black Chinese tea of a smoky flavor which is known by its brand name. Therefore, the translator chooses to identify it as Chinese tea specially that the ST refers to the brand name only.

"...sipping milky cups of LapsangSouchong..."

"Lopchu tea" is another brand name for fine black Indian tea.

$$
\text { "بينما ترتشف كوبًا تلو الآخر من الثابي الصيني (لابسانغسوشُنغ) ..." (223) }
$$

"He will watch his mother do what his father used to do toward the end of every party, spooning fine-leaf Lopchu tea into two kettles" (290).

"سبر اقب غو غول و الدته تفعل ما اعتاد و الده فعله بعد نهاية كل حفلة؛ إعداد إبريقيْ شاي من شاي لوبشو الهندي الفاخر" (466).

19. The source text is rich with many references to different types of drinks known by their brand terms such as "Pernods"(/p 3:n o:/) (231)- a French alcoholic drink with anise flavor- "Campari" (/kəmbæri/) (283)- an Italian alcoholic liquor which is often used in cocktails and is commonly served with soda water or citrus juice. The translator transliterates both:

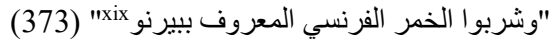

$$
\begin{aligned}
& \text { "حيث جلس يرتشف مشروب الكمباري الإيطالي أو كوبًا من القهوة" (455). }
\end{aligned}
$$

20. Other types of wine have different colors and well known by their brand terms. "Chardonnay or Chablis [ja.bli] " (219) are white and red French wine. So, the translator uses their color next to their brand names to translate them though the ST does not refer to the color. The translation is:

"....إن كانت عائلة غو غول تفضل ...نبيذًا أبيضًا (شاردونيه) أم نبيذًا أحمرًا (شابلي)" (355) (35).

21. Transliterated words sometimes seem meaningless to the reader of the TT. For instance, a "Suede jacket" (31) is not a jacket necessarily made in Sweden! The reference here is to Suede leather made from the underside of the skin primarily lamb. Similarly, the "Rickshaw" (31) is a two or three-wheeled cart pulled by one man. Without footnotes which explain the meaning of each word, the TT is confusing.

"They saw him walking to Harvard Yard in a pair of threadbare trousers, a fringed Suede jacket, and rubber flip-flops. Rickshaw drivers dress better than professors here" (31). 
The translation:

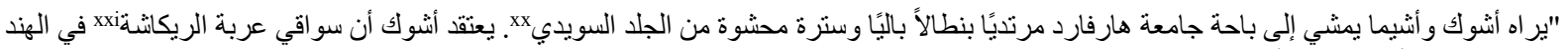

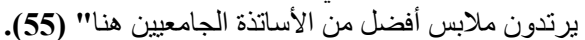

22. Other clothes terms such as "parka" (109)- a type of a jacket or a coat with a hood- "Capri pants" (128)- crop pants or three-quarter pants- "fedora and berets (UK/'berei/ or US /bo'rei/) hats" (205)- the earlier looks like a cowboy hat while the latter is a soft, round, flat-crowned hat- are transliterated because they have become trade names and the footnotes explain the distinguishing features of each.

$$
\begin{aligned}
& \text { التي كان يرتديها." (182)xxii)(parka)"فتح نيكيل سحاب سترة الباركة }
\end{aligned}
$$

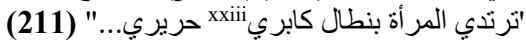

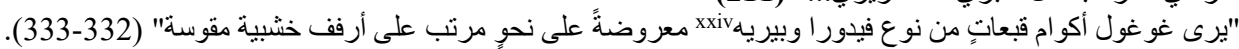

23. The "salwar kameez" (175) or 'shalwarkameez' that Ashima wears is a traditional outfit originating in South Asia and well known in the source culture. However, in the target language the equivalent translation suggest simply trousers and a body shirt. The 'shalwar' is not just trousers but a form of baggy trousers, the legs are wide at the top, and narrow at the ankle and in Arabic it is merely:

sirwal (سروال

'Kameez' is a long shirt. The translator chooses to transliterate 'shalwar' to emphasize its traditional design.

وو الدته ترتدي شلو ار قميص xxv الذي كانت تخجل من ارتدائه أمام أقربائها في كلكتا، الذين توقعو ا دائمًا أن يروها مرتديةً الساري.

24. The "duffel bag" (106) as well is a large cylindrical bag made of cloth or thick fabric. The name comes from Duffel, a town in Belgium and has become a trade mark for this kind of bags. The word is transliterated:

"ويحمل حقيبة الدفيلxxvi الخاصة به المليئة بكتبه و غسيله المتسخ" (177)

25. Other terms which describe pieces of furniture introduce a new challenge for the translator. For instance, the confusing reference to Gogol's "futon and his table..." (139). The "futon"-traditionally Japanese- is a thin mattress placed on a floor or on a raised, foldable frame. It is almost always placed on a configurable wood or metal frame for dual use as a bed and a chair or couch. In the western context, a "futon" is a couch. The translation is:

"يُقي غو غول أريكة الفوتون ومنضدته و إبريق تسخين الماء ومحمصته الكهربائية وجهاز التلفاز وبقية أشيائه...." (230).

26. The "Adirondack chairs" which Maxine's parents sits on (151) are special kind of chairs. They are wooden outdoor chairs which were first designed in the Adirondack Mountains in 1903. The term "Adirondack" has become a trade mark of outdoor wooden chairs, therefore, the term is transliterated while adding the adjective "wooden":

"They walk toward her parents, who are sitting on Andirondack chairs on the grass..." (151).

"يمشيان باتجاه و الدي ماكسين اللذين كانا يجلسان على مقعدي أديرونداك خشبيين فxvii فوق العشب..." (249).

27. Likewise, phrases which have developed into slogans are usually distinctive features of specific cultures. "...BAN THE BRA!" (31) is a vague phrase in the TL. The literal translation becomes meaningful through a footnote which shows its relation to women's protesting for equal rights in the sixties. The bra became a stereotype for a housewife and a mother depending on their men. So, burning the bra was one step towards independence.

"The Montgomerys have a dull green Volkswagen van covered with stickers: ...BAN THE BRA! PEACE!" (31) The translation:

"تمتلك عائلة البروفيسور مونتيغومري سيارة فوكسفاجن عائلية لونها أخضرّ رتيب، تغطيها ملصقات مختلفة مثل:... "حظر الصدرية"xxiii، "السلام!"

28. Some technical terms are translated and transliterated at the same time. The transliterated words have become part of the target culture. "The Walkman" (84) is:

Gogol's "sketches" (179) are:

The "fiberglass floor of the tub" (278) is:

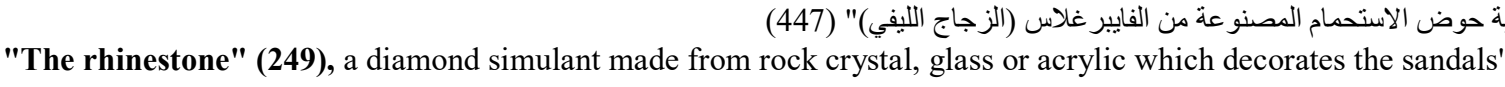
straps, are:

"...يشبه في تصميمه صندل المصار ع اليوناني؛ له أشرطةٌ جلديةٌ مزينةٌ بأحجار الر اين (الماس المزيف)" (402). 29. On the contrary, other technical terms have no equivalence in the target language such as "plexiglass" (199)- a transparent acrylic plastic often used in place of glass -"Lucite" (249)- another fine type of plastic which has become a trademark - and "linoleum" (1)- a floor covering. The translation is:

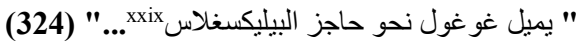

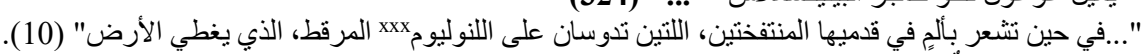

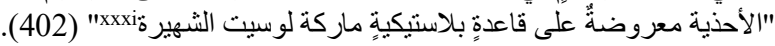

\section{Conclusion}

Edwar Sapir (1956) claims that human beings are at the mercy of the language that has become the medium of expression for their society and culture. Cultural differences may create irrelevant or even damaging translation. Sapir clarifies:

"No two languages are ever sufficiently similar to be considered as presenting the same social reality. The worlds in which different societies live are distinct worlds, not merely the same world with different labels attached" (69).

Yinhua (2011) says, "As far as the whole text is concerned, it is simply impossible to transfer all the message of the original text into the target text" (169). Despite the fact that translation brings cultures closer, it may also lead to a deformation of the original culture. However, the choice of including more 'foreign' words in the translated prose will 
always be available for the translator. Thus, Derrida (1985) describes the task of the translator: "To redeem in his own tongue that pure language exiled in the foreign tongue, to liberate by transposing this pure language captive in the work" (188). The translator has a very challenging task as Spivak (1993) suggests: "The translator is not only part of her community of readers: she also comes in contact with another community, negotiating with it, taking part with it...[she] is one [who] works with a language that belongs to many others" (179). Not any bilingual individual is able to produce an accurate translation of the ST. The translator needs to understand the author's thought and the culture which has produced the text in order to render an accurate translation. Indeed, the translated text is the "locus of encounter of two traditions, authorships and authorities" (Santiago cited in Daly and Vieira, 1999).

Finally, this paper is a practical witness on the challenges faced by the translator when dealing with a literary text written in prose. The researcher suggests that there is a need to expand the perimeters of translation studies specially those dealing with literary prose because the translators and researchers lay more emphasis on the translation of poetry.

\section{References}

Bassnett, S. (1980). Translation Studies. London: Methuen \& Co. Ltd.

Benjamin, W. (1968). Illuminations (H. Zohn, Trans). New York: Shocken Books.

Bhabha, H. K. (1994). The Location of Culture. London: Routledge.

Catford, J. C. (1965). A Linguistic Theory of Translation. London: Oxford UP.

Derrida, J. (1985). "Des Tours Des Babel". In Difference in Translation, edited by J. F. Graham. Ithaca Cornell UP.

Haque, Ziaul. (2012). "Translating Literary Prose: Problems and Solutions". International Journal of English and Linguistics. 2 (6): 97- 111.

Jakobson, R. (1959). "On Linguistic Aspects of Translation." In On Translation, edited by R. A.Brower, 113-118.

Cambridge: Harvard UP.

Lahiri, Jhumpa.(2003). The Namesake. New York: Houghton Mifflin Company.

Lahiri, Jhumpa.2015. The Namesake.[In Arabic].Translated by SuraKhrais. Abu Dhabi: Kalima Publishers, Abu Dhabi

Tourism and Culture Authority.

Newmark, P. (1988). A Textbook of Translation. New York \& London: Prentice Hall.

Nida, E. A. \& C. R. Taber. (1982). The Theory and Practice of Translation. Leiden: E. J. Brill.

Sapir, E. (1956). Culture, Language and Personality. Berkeley, Los Angeles: University of California Press.

Spivak, G. C. (1993). "The Politics of Translation". In Outside in the Teaching Machine, 179-200. New York and

London: Routledge.

Vieira, E. R. P. (1999). "'The White Wall': Pre-Facing SilvianoSatiago". In SilvianoSatiago in Conversation, edited by Daly, M. Daly \&. E. R. P. Vieira, 7-15. Zoilus Press: London.

Yinhua, X. (2011). "Equivalence in Translation: Features and Necessity." International Journal of Humanities and Social Sciences, 1 (10): 169-171.

www.wordreference.com/aren/

dictionary.cambridge.org/dictionary

idioms.thefreedictionary.com/swear

\section{Notes}

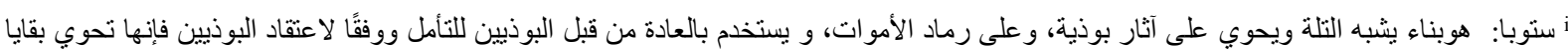

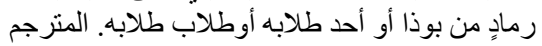

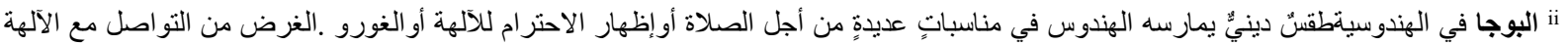

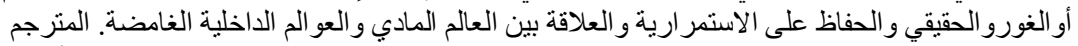

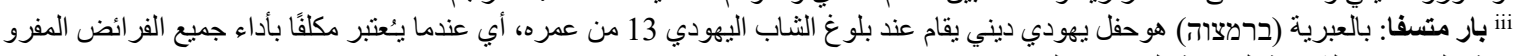

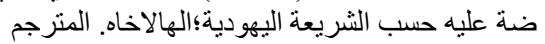

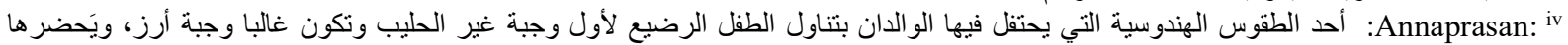

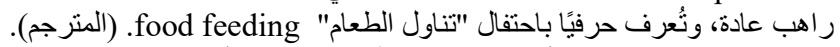
:Doric pilasters:

$$
\text { المترجً }
$$

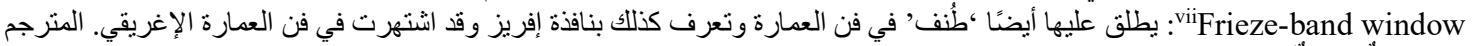

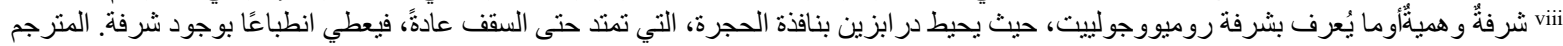

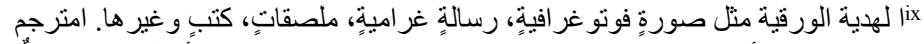

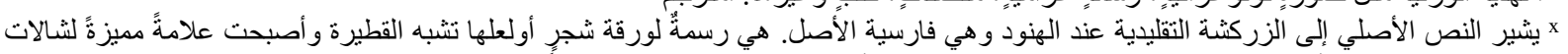

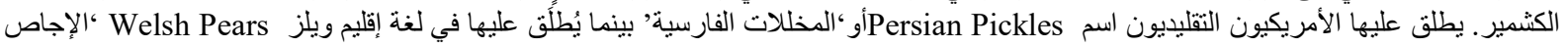
الويلزي'. المترجم

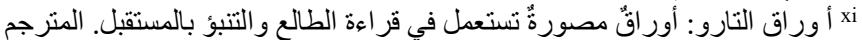

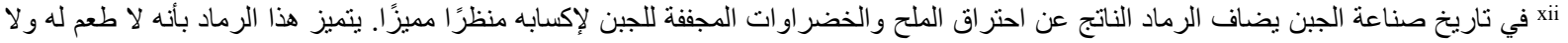
رائحة. المنرجم فاربخ

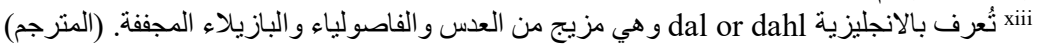

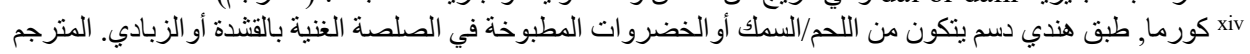




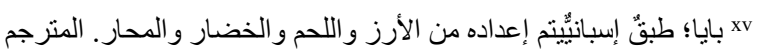

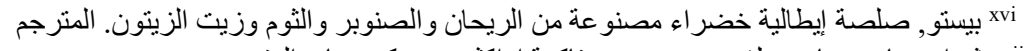
شvii

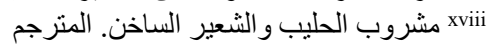

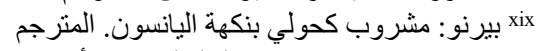
Suede jacket xx Rickshaw xxi

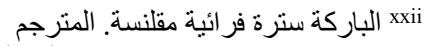
بناء xxiii

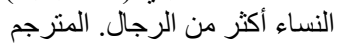

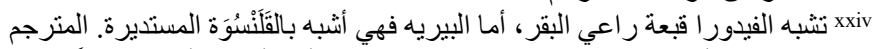

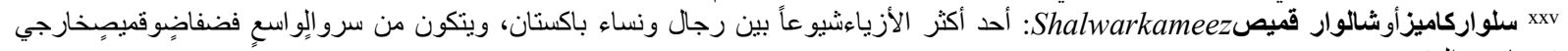
فضفاض. المترجم ميلواميز هovi

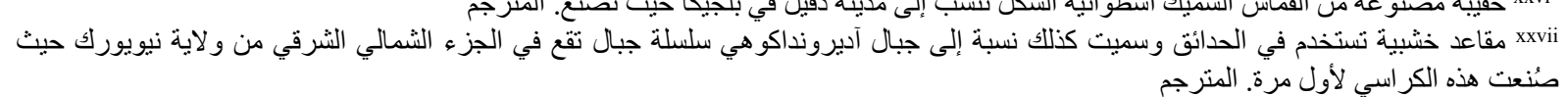

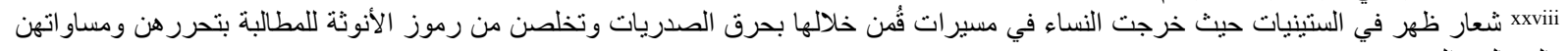
بالرجال. (المترجم).

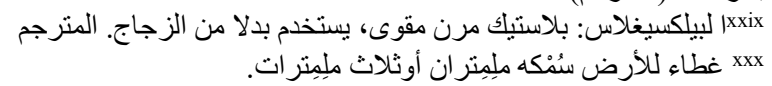

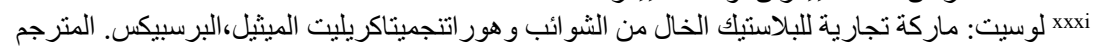

